\title{
Highly efficient L-lactate production using engineered Escherichia coli with dissimilar temperature optima for L-lactate formation and cell growth
}

Dandan Niư ${ }^{1 *}$, Kangming Tian ${ }^{1}$, Bernard A Prior ${ }^{2}$, Min Wang ${ }^{1}$, Zhengxiang Wang ${ }^{1}$, Fuping $\mathrm{Lu}^{1}$ and Suren Singh ${ }^{3}$

\begin{abstract}
L-Lactic acid, one of the most important chiral molecules and organic acids, is produced via pyruvate from carbohydrates in diverse microorganisms catalyzed by an $\mathrm{NAD}^{+}$-dependent L-lactate dehydrogenase. Naturally, Escherichia coli does not produce L-lactate in noticeable amounts, but can catabolize it via a dehydrogenation reaction mediated by an FMN-dependent L-lactate dehydrogenase. In aims to make the E. coli strain to produce L-lactate, three $L$-lactate dehydrogenase genes from different bacteria were cloned and expressed. The L-lactate producing strains,

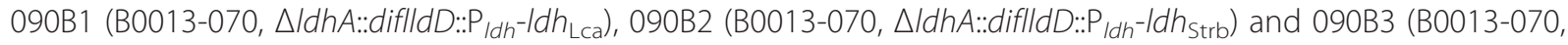
$\triangle / d h A::$ diflldD:: $\left.P_{1 d h}-1 d h_{B c o a}\right)$ were developed from a previously developed D-lactate over-producing strain, $E$. coli strain B0013-070 (ack-ptappspflBdldpoxBadhEfrdA) by: (1) deleting IdhA to block D-lactate formation, (2) deleting $\| d D$ to block the conversion of L-lactate to pyruvate, and (3) expressing an L-lactate dehydrogenase (L-LDH) to convert pyruvate to L-lactate under the control of the IdhA promoter. Fermentation tests were carried out in a shaking flask and in a 25-I bioreactor. Strains 090B1, 090B2 or 090B3 were shown to metabolize glucose to L-lactate instead of D-lactate. However, L-lactate yield and cell growth rates were significantly different among the metabolically engineered strains which can be attributed to a variation between temperature optimum for cell growth and temperature optimum for enzymatic activity of individual L-LDH. In a temperature-shifting fermentation process (cells grown at $37^{\circ} \mathrm{C}$ and L-lactate formed at $42^{\circ} \mathrm{C}$ ), E. coli 090B3 was able to produce $142.2 \mathrm{~g} / \mathrm{l}$ of L-lactate with no more than $1.2 \mathrm{~g} / \mathrm{l}$ of by-products (mainly acetate, pyruvate and succinate) accumulated. In conclusion, the production of lactate by $E$. coli is limited by the competition relationship between cell growth and lactate synthesis. Enzymatic properties, especially the thermodynamics of an L-LDH can be effectively used as a factor to regulate a metabolic pathway and its metabolic flux for efficient L-lactate production.
\end{abstract}

Highlights: The enzymatic thermodynamics was used as a tool for metabolic regulation. minimizing the activity of L-lactate dehydrogenase in growth phase improved biomass accumulation. maximizing the activity of L-lactate dehydrogenase improved lactate productivity in production phase.

Keywords: L-Lactate, L-Lactate dehydrogenase, Enzymatic thermodynamics, Metabolic engineering

\footnotetext{
* Correspondence: ddniu@tust.edu.cn

'Key Laboratory of Industrial Fermentation Microbiology, Ministry of

Education \& The College of Biotechnology, Tianjin University of Science \&

Technology, Tianjin 300457, China

Full list of author information is available at the end of the article
} 


\section{Introduction}

L-Lactic acid, one of the two lactic acid optical isomers, is produced via pyruvate from carbohydrates in diverse microorganisms catalyzed by an $\mathrm{NAD}^{+}$-dependent L-lactate dehydrogenase [1]. L-Lactic acid is generally supplemented to foods or feeds as an excellent sour agent or $\mathrm{pH}$ modulator [2]. L-Lactic acid is also an important precursor for synthesis of chiral compounds such as chiral drugs and chiral pesticides $[3,4]$ and, more importantly, as a monomer for the synthesis of poly-L-lactic acid, a biodegradable and environmental friendly polymer $[2,5]$.

In contrast to past applications of racemic lactic acid, L-lactic acid as a monomer for poly-L-lactic acid synthesis must possess the highest optical purity and chemical purity [6,7], Recently L-lactate production by microbial has been extensively investigated for this reason.

In previous works, metabolically engineered $E$. coli has been shown to be a suitable host for large-scale production of D-lactic acid or L-lactic acid, and several metabolically-engineered $E$. coli strains have been successfully constructed for efficient synthesis of D-lactic acid or L-lactic acid of high optical [8-12]. For L-lactic acid formation, E. coli strains are usually genetically modified to: (1) create a pathway for L-lactic acid formation, (2) block the pathway for L-lactic acid catabolism, and (3) construct/block pathways connected with intermediates for L-lactic acid [12-16].

Generally, L-lactate (and some other organic acids) is formed during cell growth, which negatively affects cell activity and cell growth and, as a consequence, exerts a detrimental effect on L-lactate titer and yield. The L-lactic acid synthesis pathway being less active during cell growth could be positive for cell growth and finally for L-lactic acid titer and yield as this strategy has been confirmed to be effective in D-lactate synthesis in E. coli $[11,17,18]$.

It is expected that effectively controlling intracellular lactate dehydrogenase activity is crucial to achieve efficient lactate synthesis under fermentation process. Here, we described a new strategy to assess this proposal by engineering an L-lactate synthesis pathway in $E$. coli with temperature optima different between cell growth and a heterologously expressed bacterial L-lactate dehydrogenase. The strain expressed an L-lactate dehydrogenase from a thermophilic bacterium showed robust growth at its temperature optimum and was more efficient in fermenting glucose to L-lactate with less by-products formation at an elevated temperature.

\section{Materials and methods}

\section{Strains}

The genotypes of the microbial strains and plasmids used in the present study are summarized in Table 1. Escherichia coli strain 070 ( $\Delta a c k$-pta::dif $\Delta p p s::$ dif $\Delta p f l B::$ dif $\Delta$ dld::dif $\Delta-$ poxB::FRTAadhE::dif $\triangle$ frdA::dif) was reported previously
[10]. Strain 090B1 (070, $\Delta l d h A::$ diflldD::ldhAp-ldh $\left.h_{\mathrm{Lca}}\right)$, 090B2(070, $\Delta l d h A::$ diflldD::ldhAp-ldh $\left.h_{\text {Strb }}\right)$ and 090B3 $\left(070, \Delta l d h A:: d i f l l d D:: l d h A p-l d h_{\text {Bсоа }}\right)$ were constructed during this study. DNA manipulations were performed using conventional techniques [19].

To construct the 090B1, 090B2 and 090B3, ldhA in strain 070 encoding a D-lactate dehydrogenase for conversion of pyruvate to D-lactate was deleted followed by placing $l d h A p-l d h_{\mathrm{Lca}}, l d h A p-l d h_{\mathrm{Strb}}$ or $l d h A \mathrm{p}-l d h_{\mathrm{Bcoa}}$ expression cassette which encodes an L-lactate dehydrogenase under the control of $l d h A$ promoter for conversion of pyruvate to Llactate from different microorganisms in the middle of the chromosomal $l l d D$ gene in strain $080 C(070, \Delta l d h A:$ diff).

\section{Deletion of IdhA to obtain E. coli B0013-080C}

The $l d h A^{\prime}$ gene was cloned from the genomic DNA of $E$. coli B0013-070 using PCR amplification and the primers LdhA1 and LdhA2. The PCR product was purified and cloned into pMD18-T simple vector to yield plasmid pMD-ldhA'. This plasmid was digested with SalI and $K p n I$ and blunted by incubation with $P f u$ DNA polymerase, which was then ligated with a selectable marker $\left(\mathrm{Gm}^{\mathrm{R}}\right.$ with dif sites flanked) isolated from pSK-dif $\mathrm{Gm}^{\mathrm{R}}$ [10], to yield a hybrid plasmid pMD-ldhA::Gm, in which a 212 bp fragment in the middle of $l d h A$ in pMD-ldhA was removed and replaced with diff $\mathrm{Gm}$. The deletion cassette, ldhA'-difGm-dif-ldhA', was recovered from pMDldhA::Gm with EcoRI digestion and agarose gel isolation. The deletion cassette was electro-transformed into strain B0013-070 and $l d h A$ disruption mutant was selected by the method described previously $[10,11]$. The resulting recombinant strain was designated 080C (B0013-070, $\Delta l d h A:$ :dif).

\section{Expression of $I d h$ and disruption of $I I d D$}

The E. coli ldhA gene was cloned from the genomic DNA of B0013-070 using PCR amplification and the primers LdhA3 and LdhA4. The resulting 1.6-kb PCR fragment, which included the promoter, the structural region of the $l d h A$ gene and the terminator, was inserted into the pMD18-T simple vector to create pMD-ldhA. The reverse PCR fragment from plasmid PMD-ldhA was amplified using the primers RldhA1 and RldhA2. The amplified fragment was then self-ligated to create an expression plasmid, pLDHex. The $l d h_{\mathrm{Bcoa}}$ gene encoding a Bacillus coagulans L-LDH was recovered from the genome by PCR amplification with primers BcoaLDH1 and BcoaLDH4. After digestion with BamHI and EcoRI, this 885-bp fragment was cloned into the BglII and EcoRI

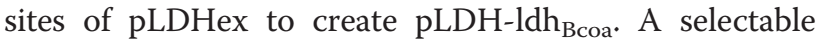
marker, dif $\mathrm{Gm}\left(\mathrm{Gm}^{\mathrm{R}}\right.$ with dif sites flanked) isolated from pSK-difGm ${ }^{\mathrm{R}}$ [10], was subcloned into the EcoRV site of pLDH-ldh ${ }_{\text {Bcoa }}$ to create pLDH-ldh Bcoa $-\mathrm{Gm}$. Similarly, pLDH-ldh ${ }_{\text {Strb }}-$ Gm was created by cloning a 1,464-bp $l d h_{\text {Strb }}$ (encoding a Streptococcus bovis L-LDH) digested 
Table 1 Strains and plasmids used in this study

\begin{tabular}{|c|c|c|}
\hline Strains & Relevant characteristics & Source or reference \\
\hline Escherichia coli B0013-070 & B0013, $\triangle a c k-p t a, \Delta p p s, \Delta p f l B, \Delta d l d, \Delta p o x B, \triangle a d h E, \Delta$ frdA & [10] \\
\hline E. coli B0013-080C & B0013-070, $\triangle / d h A$ & This study \\
\hline E. coli B0013-090B1 & B0013-080C, $\Delta / / d D:: / d h A p-I d h_{\text {Lca }}$ & This study \\
\hline E. coli B0013-090B2 & B0013-080C, $\Delta / / d D:: / d h A p-l d h_{\text {Strb }}$ & This study \\
\hline E. coli B0013-090B3 & B0013-080C, $\Delta / / d D:: / d h A p-I d h_{\text {Bcoa }}$ & This study \\
\hline Bacillus coagulans B1821 & Wild type & CICIM-CU \\
\hline Lactobacillus casei B1192 & Wild type & $\mathrm{CICIM}-\mathrm{CU}^{\mathrm{a}}$ \\
\hline Steptococcus. bovis 1.1624 & Wild type & CGMCC $^{b}$ \\
\hline Plasmids & Relevant characteristics & Source or reference \\
\hline pSK-difGm ${ }^{R}$ & difGm, bla & [20] \\
\hline pMD18-T simple & bla; TA cloning vector & TaKaRa, Japan \\
\hline pLDHex & bla; $\mathrm{P}_{\text {ldhA, }} \mathrm{T}_{\text {ldhA }}$ & This study \\
\hline
\end{tabular}

${ }^{\mathrm{a}}$ The Culture and Information Center of Industrial Microorganisms of China Universities, Jiangnan University, China.

${ }^{b}$ China General Microbiological Culture Collection Center, Institute of Microbiology, CAS, Beijing, China.

with BamHI and EcoRI into the BglII and EcoRI sites of pLDHex followed by inserting difGm into the EcoRV site. For development of pLDH-ldh $\mathrm{Lca}-\mathrm{Gm}, \mathrm{PCR}$ amplified 1.26-kb fragment of $l d h_{\text {lca }}$ (encoding a Lactobacillus casei L-LDH) was first cloned into the BglII and PstI sites of pLDHex to yield pLDH-ldhLca followed by insertion of difGm from pSK-difGm ${ }^{\mathrm{R}}[10]$ into the EcoRV site. Meanwhile, the whole length of $l l d D$ was amplified from the genomic DNA of E. coli B0013 with primers LldD1 and LldD2. The resulting PCR 1154-bp fragment was cloned into pMD18-T simple vector to create $\mathrm{pMD}$ lldD. Afterwards, the $l d h$ expression cassette $\left(\mathrm{P}_{l d h A}-l d h\right.$ $\mathrm{Gm})$ was isolated from pLDH-ldh $\mathrm{Lca}-\mathrm{Gm}, \mathrm{pLDH}-\mathrm{ldh}_{\mathrm{Strb}^{-}}$ $\mathrm{Gm}$, or pLDH-ldh $\mathrm{Bcoa}-\mathrm{Gm}$ with BamHI digestion and gel purification and cloned into the BamHI sites of pMD-lldD to create pMD-lldD:: $\mathrm{P}_{l d h A}-l d h_{\mathrm{Lca}}-\mathrm{Gm}, \mathrm{pMD}-$ lldD:: $\mathrm{P}_{l d h A^{-}}-l d h_{\mathrm{Strb}}-\mathrm{Gm}$, or pMD-lldD:: $\mathrm{P}_{l d h A}-l d h_{\mathrm{Bcoa}}-\mathrm{Gm}$, in which a 39-bp BamHI-fragment was deleted in the middle of $l l d D$. These plasmids were digested with SmaI and the resulting deletion/expression cassettes were gel isolated and electroporated into strain B0013-080C The recombinants were selected by the method described previously $[10,18]$. The resulting recombinant strains were designated 090B1 (B0013-080C, $\left.\Delta l l d D:: \mathrm{P}_{l d h A^{-}} l d h_{\mathrm{Lca}}\right)$,

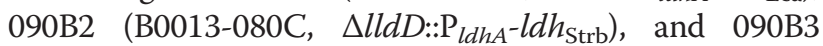
(B0013-080C, $\left.\Delta l l d D:: \mathrm{P}_{l d h A}-l d h_{\mathrm{Bcoa}}\right)$.

Details of the primers used in this study are provided in Table 2.

\section{Measurement of LDH activity}

Strains (stored as glycerol stocks at $-80^{\circ} \mathrm{C}$ ) were first grown on Luria-Bertani (LB) plates for approximately $24 \mathrm{~h}$ at $37^{\circ} \mathrm{C}$ and then the colonies were transferred to $50 \mathrm{ml}$ of LB medium in a $250-\mathrm{ml}$ flask. After growing

Table 2 Primers used in this study

\begin{tabular}{|c|c|c|}
\hline Primers & Sequence (5'-3') restriction sites are italic/underlined & Restriction sites \\
\hline LdhA1 & TAAGAATTC ${ }^{\mathrm{a} T T A T G A A A C T C G C C G T T T A T A G C A C A}$ & $E C O R l^{\mathrm{a}}$ \\
\hline LdhA2 & CTTGAATTC ${ }^{\mathrm{a}} A$ AGCTT ${ }^{\mathrm{a}} \mathrm{GCTGCCGGAAATCATCATTTIT}$ & EcoRl|, HindIII ${ }^{a}$ \\
\hline LdhA3 & GGGCAGCCCGAGCGTCATCAG & \\
\hline LdhA4 & GCTGCCGGAAATCATCATITIIT & \\
\hline BcoaLDH1 & CCGGATCC AATCAGGGTGTTGCAGAAGAGCTTG & $B a m H^{a}$ \\
\hline BcoaLDH4 & GCGGAATTCTTACAATACAGGTGCCATCGTTTCT & $\left.E C O R\right|^{\mathrm{a}}$ \\
\hline LcaLDH1 & CGCGGATCCAAGTATTACGGATAAGGATCAC & $B a m H^{a}$ \\
\hline LcaLDH4 & CGCCTGCAG ${ }^{a}$ TCCTGTTCTTCGTTG & Pst $\left.\right|^{a}$ \\
\hline StrbLDH1 & CGCGGATCC ${ }^{\mathrm{a} A C T A A A C A A C A C A A A A A A G}$ & $B a m H^{a}$ \\
\hline StrbLDH2 & CCGGAATTC ${ }^{\mathrm{a}}$ TACAGGGATTGTTGCCGCA & $E C O R l^{a}$ \\
\hline LldD1 & GGCCCGGGa'CATGATTATTTCCGCAGCCA & $\left.S m a\right|^{a}$ \\
\hline LldD2 & GGCCCGGGa CAGGCAACTCTITACCCAGCCC & $\left.S m a\right|^{a}$ \\
\hline
\end{tabular}

${ }^{\mathrm{a}}$ Restriction sites with corresponding restriction enzyme. 
while shaking at $200 \mathrm{rpm}$ for $7 \mathrm{~h}$, the cells were collected and crude cell extracts were prepared using the bacterial soluble total protein preparation kit (GENMED Scientifics Inc., Arlington, MA, USA). The extracts were assayed for LDH activity using a kit to colorimetrically determine the total bacterial LDH activity (GENMED Scientifics Inc., Arlington, MA, USA) at $\mathrm{pH} 6.5$ and at the same temperature as that of incubation $\left(25^{\circ} \mathrm{C} \sim 50^{\circ} \mathrm{C}\right)$. One unit of the overall LDH activity was defined as the amount of enzyme required to transform $1 \mu$ mole $\mathrm{NADH}$ to $\mathrm{NAD}^{+}$ per minute. The protein concentration in the crude extracts was determined using the Bradford method, and bovine serum albumin was used as the standard. The LDH activity was divided by the corresponding protein concentration to calculate the specific LDH activity. The assays are performed in triplicates.

\section{Flask fermentation experiments}

The flask fermentation experiments were carried out according to the previous publication $[10,17]$ in $250 \mathrm{ml}$

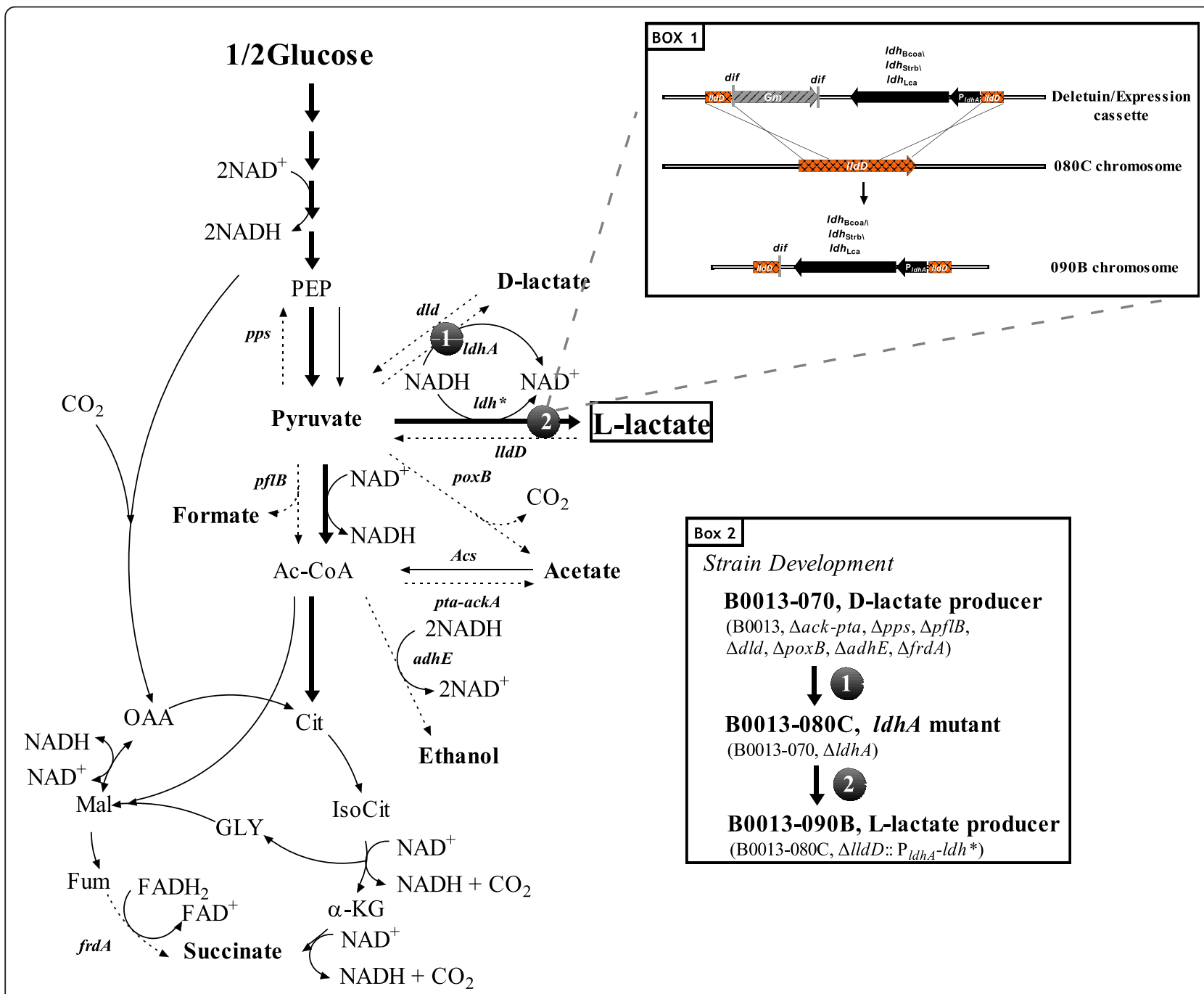

Figure 1 The metabolic pathways for the production of L-lactate by engineered $E$. coli from glucose. Relevant genes are shown. pps, PEP synthase; $P f I B$, pyruvate formatelyase; IdhA, fermentative D-lactate dehydrogenase; dld, D-lactate dehydrogenase; poxB, pyruvate oxidase; pta, phosphotransacetylase; ackA, acetate kinase; adhE, alcohol dehydrogenase; frdA, fumaratereductase; IIdD, FMN-dependent L-lactate dehydrogenase;

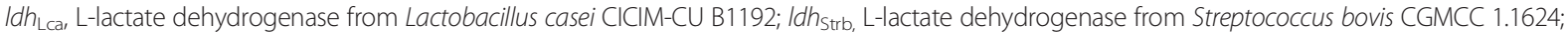
Id $h_{\mathrm{Bco}}$, L-lactate dehydrogenase from Bacillus coagulans CICIM B1821. Box A presented the homologous recombination on the chromosome in B0013-090B series. The deletion/expression cassette was first electroporated into E. coli B0013-080C. The transformants were selected within LB medium containing gentamicin and the correct double replacement recombinants were confirmed by PCR. The second selection was carried out by incubating the correct recombinants in LB medium without gentamicin. The correct recombinants were confirmed by PCR. Box B outlined the construction procedure for B0013-090B1, and B0013-090B2 and B0013-090B3. PlacA-ldh* represented one expression cassette of $/ d h_{L c a} / d h_{S t r b}$ and $/ d h_{B c o a} u n d e r$ the control the promoter of E. coli IdhA. Abbreviations: PEP, phosphoenolpyruvate; Ac-CoA, acetyl-CoA; Cit, citrate; IsoCit, isocitrate; $\mathrm{a-KG}$, a-ketoglutarate; Fum, fumarate; Mal, malate; OAA, oxaloacetate; GLY, glyoxylate. 
flasks with the working volume of $50 \mathrm{ml}$. Briefly, cells were grown in $50 \mathrm{ml}$ of LB medium in a $250 \mathrm{ml}$ flask at $37^{\circ} \mathrm{C}$ with shaking $(200 \mathrm{rpm})$ for $8-10 \mathrm{~h}$ until cell density $\left(\mathrm{OD}_{600}\right)$ of 2.0-2.5 was reached. Cells were collected by centrifugation and resuspended in a modified M9 medium and then inoculated into $50 \mathrm{ml}$ of the modified M9 medium complemented with $5 \mathrm{~g} / \mathrm{l}$ glucose in a $250 \mathrm{ml}$ flask with the initial cell density $\left(\mathrm{OD}_{600}\right)$ of 0.05 . For cell growth experiments, the cultivation was carried out at shaking speed of $200 \mathrm{rpm}$ and at different temperatures. For lactate fermentation, the cultivation was first carried out at $37^{\circ} \mathrm{C}$ and $200 \mathrm{rpm}$ for $12 \mathrm{~h}$, then $30 \mathrm{~g} / \mathrm{l}$ glucose was added followed by stationary cultivation (anaerobic fermentation) for lactate formation at different temperatures. Calcium carbonate with a final concentration of $75 \mathrm{~g} / \mathrm{l}$ was added for neutralization. Sampling was carried out during the cultivation. Modified M9 medium contained

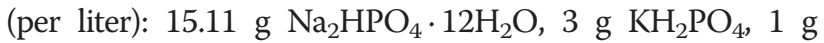
$\mathrm{NH}_{4} \mathrm{Cl}, 0.5 \mathrm{~g} \mathrm{NaCl}$. One ml of filter-sterilized $1 \mathrm{M} \mathrm{MgSO}_{4}$, and $1 \mathrm{ml}$ of filter-sterilized trace element solution containing (per liter) $2.4 \mathrm{~g} \mathrm{FeCl}_{3} \cdot 6 \mathrm{H}_{2} \mathrm{O}, 0.3 \mathrm{~g} \mathrm{CoCl} \cdot 6 \mathrm{H}_{2} \mathrm{O}, 0.15 \mathrm{~g}$ $\mathrm{CuCl}_{2} \cdot 2 \mathrm{H}_{2} \mathrm{O}, 0.3 \mathrm{~g} \mathrm{ZnCl}_{2}, 0.3 \mathrm{~g} \mathrm{Na}_{2} \mathrm{MO}_{4} \cdot 2 \mathrm{H}_{2} \mathrm{O}, 0.075 \mathrm{~g}$ $\mathrm{H}_{3} \mathrm{BO}_{3}, 0.495 \mathrm{~g} \mathrm{MnCl}_{2} \cdot 4 \mathrm{H}_{2} \mathrm{O}$ was added to a liter of the final medium.

\section{Fed-batch fermentation in bioreactor}

A fed-batch fermentation experiment in bioreactor was carried out according to the method described $[10,11,21]$. A 25-1 bioreactor (Bioflow110; New Brunswick Scientific Co., Inc., Edison, NJ), initially containing 111 of the modified M9 medium as above in the "Flask fermentation experiments", was used for L-lactate production from glucose. The two-phase fed-batch process was started by inoculating $600 \mathrm{ml}$ fresh inoculum prepared by preculturing cells in LB medium as described above. The cells were cultivated in the aerobic condition followed by anaerobic fermentation. Anaerobic fermentation for L-lactate formation was initiated by ceasing air sparging and reducing agitation to $100 \mathrm{rpm}$ when the cell density $\left(\mathrm{OD}_{600}\right)$ reached about 30 (which is equal to about $11.4 \mathrm{~g} / \mathrm{l}$ dry cell weight (DCW)). During the aerobic phase, glucose was supplemented with $30 \mathrm{~g} / \mathrm{l}$ for cell growth and the culture was grown at $\mathrm{pH} 7.0$ controlled by automatically feeding $25 \%(\mathrm{w} / \mathrm{v}) \mathrm{NH}_{4} \mathrm{OH}$ solution and the dissolved oxygen tension controlled above 30\% of saturation. During the anaerobic phase, the $\mathrm{pH}$ was controlled at 7.0 by the addition of $25 \%(\mathrm{w} / \mathrm{v}) \mathrm{Ca}(\mathrm{OH})_{2}$. The residual glucose concentration was maintained above $10 \mathrm{~g} / \mathrm{l}$ by adding glucose in four batches $(649.5 \mathrm{~g}$ of glucose was added in total). The fermentations were stopped when the glucose was exhausted.

\section{Cultivation conditions for exploiting growth properties} Strains B0013-090B1, B0013-090B2 or B0013-090B3 heterologously expressing an L-lactate dehydrogenase (L-LDH) were examined for their growth rate and L-LDH activity. A shake flask fermentation test was carried out in a $250-\mathrm{ml}$ flask with working volume of $50 \mathrm{ml}$ at various temperatures from $25^{\circ} \mathrm{C}$ to $50^{\circ} \mathrm{C}$ for up to $14 \mathrm{~h}$. The cell density was analyzed with the method as described below in the "Analytical methods". The intracellular lactate dehydrogenase activities in strains B0013-090B1, B0013-090B2 and B0013-090B3 grown for $7 \mathrm{~h}$ were determined.

\section{Analytical methods}

The cell mass was estimated by measuring the optical density at $600 \mathrm{~nm}$ (if $\mathrm{CaCO}_{3}$ or $\mathrm{Ca}(\mathrm{OH})_{2}$ had been added during fermentation, samples were pretreated with $1 \mathrm{M}$ $\mathrm{HCl}$ at 20 -fold of the sample volume to remove the suspended substances), and the dry weight of the cells was calculated using a standard curve $\left(1 O D_{600}=0.38 \mathrm{~g} / \mathrm{l}\right.$ DCW) [10]. The glucose concentration was estimated using a glucose biosensor [10]. Samples were pretreated with $\mathrm{H}_{2} \mathrm{SO}_{4}$ (at $5 \%$ of the sample volume) to release organic acids that precipitated with $\mathrm{CaCO}_{3}$ or $\mathrm{Ca}(\mathrm{OH})_{2}$

Table 3 Lactate formation in flask fermentation

\begin{tabular}{lllc}
\hline Strain & L-lactate $\left(\mathbf{g} / \mathbf{l}^{\mathbf{a}}\right.$ & D-lactate $(\mathbf{g} / \mathbf{l})^{\mathbf{a}}$ & Yield of L-/D-lactate $\left(\%, w / w\right.$, based on total supplied glucose) $^{\mathbf{a}}$ \\
\hline B0013-090B1 & $20.16 \pm 0.90$ & $0.02 \pm 0.00$ & 58 \\
B0013-090B2 & $16.19 \pm 0.92$ & $0.03 \pm 0.00$ & 46 \\
B0013-090B3 & $25.59 \pm 1.08$ & $0.03 \pm 0.00$ & 73 \\
B0013-070 & $0.00 \pm 0.00$ & $27.27 \pm 1.06$ & 78 \\
B0013-080C & $0.00 \pm 0.00$ & $0.01 \pm 0.00$ & $/$ \\
\hline
\end{tabular}

${ }^{a}$ The flask fermentation experiments were carried out in $250 \mathrm{ml}$ flasks with the working volume of $50 \mathrm{ml}$. Briefly, cells were grown in $50 \mathrm{ml}$ of LB medium in a $250 \mathrm{ml}$ flask at $37^{\circ} \mathrm{C}$ with shaking $(200 \mathrm{rpm})$ for $8-10 \mathrm{~h}$ until cell density $\left(\mathrm{OD}_{600}\right)$ of 2.0-2.5 was reached. Cells were collected by centrifugation and resuspended in a modified M9 medium and then inoculated into $50 \mathrm{ml}$ of the modified M9 medium complemented with $5 \mathrm{~g} / \mathrm{l}$ glucose in a $250 \mathrm{ml}$ flask with the initial cell density $\left(\mathrm{OD}_{600}\right)$ of 0.05 in triplicates. The cultivation was first carried out at $37^{\circ} \mathrm{C}$ and $200 \mathrm{rpm}$ for $12 \mathrm{~h}$, then $30 \mathrm{~g} / \mathrm{l}$ glucose was added followed by stationary cultivation (anaerobic fermentation) for lactate formation at different temperatures. Calcium carbonate with a final concentration of $75 \mathrm{~g} / \mathrm{l}$ was added for neutralization. Sampling was carried out during the cultivation. Lactic acid concentration was measured by HPLC equipped with UV ( $210 \mathrm{~nm})$ and refractive index detectors, using a Shodex SH-1011 column (Shodex SH-1011 H610009; Showa Denko K.K., Kawasaki, Japan) with $0.01 \mathrm{M} \mathrm{H}_{2} \mathrm{SO}_{4}$ as eluent $\left(0.6 \mathrm{ml} / \mathrm{min}\right.$; $\left.50^{\circ} \mathrm{C}\right)$. Lactic acid isomeric purity was measured by HPLC using a chiral column (CLC-L; Advanced Separation Technologies Inc., Whippany, NJ, USA), at room temperature, equilibrated with $1 \mathrm{ml} / \mathrm{min}$ of $5 \mathrm{mM}$ CuSO4 as the mobile phase and detected at $254 \mathrm{~nm}$ with a UV detector. 
during fermentation. Organic acid concentrations were measured by HPLC as described previously [10]. Organic acid and ethanol concentrations were measured by HPLC equipped with UV $(210 \mathrm{~nm})$ and refractive index detectors, using a Shodex SH-1011 column (Shodex SH-1011 H610009; Showa Denko K.K., Kawasaki, Japan) with $0.01 \mathrm{M} \mathrm{H}_{2} \mathrm{SO}_{4}$ as eluent $\left(0.6 \mathrm{ml} / \mathrm{min} ; 50^{\circ} \mathrm{C}\right)$. Lactic acid isomeric purity was measured by HPLC using a chiral column (CLC-L; Advanced Separation Technologies Inc., Whippany, NJ, USA), at room temperature, equilibrated with $1 \mathrm{ml} / \mathrm{min}$ of $5 \mathrm{mM} \mathrm{CuSO} 4$ as the mobile phase and detected at $254 \mathrm{~nm}$ with a UV detector.

\section{Results}

Metabolic engineering of E. coli B0013 to produce L-lactate For L-lactate synthesis in E. coli, the following genetic manipulations have been made: (1) construction of an L-lactate synthesis pathway by expressing a heterologous L-lactate dehydrogenase, (2) elimination of the D-lactate synthesis pathway by deleting $l d h A$ encoding a D-lactate dehydrogenase, and (3) blocking of the L-lactate catabolic pathway by disrupting $l l d D$ encoding an FMNdependent L-lactate dehydrogenase (Figure 1). First, a deletion cassette $l d h A^{\prime}$-difGm-ldhA' for deletion of $l d h A$ encoding D-lactate dehydrogenase was constructed and genetically transformed into E. coli B0013-070 according to the procedures described in the method section. A mutant, designated E. coli B0013-080C (B0013-070, ldhA::dif), was constructed and confirmed by PCR. This mutant failed to form D-lactate (Table 3). Then, the respective coding regions of $l d h_{\mathrm{Lca}}, l d h_{\mathrm{Strb}}$ or $l d h_{\mathrm{Bcoa}}$ encoding an L-lactate dehydrogenase from L. casei, Str. bovis or B. coagulans were cloned and their native promoters were replaced by the promoter of E. coli ldhA. This hybrid expression cassette $\left(\mathrm{P}_{l d h A}-l d h_{\mathrm{Lca}}, \mathrm{P}_{l d h A^{-}} l d h_{\text {Strb }}\right.$ or $\left.\mathrm{P}_{l d h A^{-}} l d h_{\mathrm{Bcoa}}\right)$ was then chromosomally integrated into the lldD locus in E. coli B0013-080C by electroporating the deletion/expression cassette $l l d D:: \mathrm{P}_{l d h A^{-}}$ldh-difGm (here, $l d h$ represents $l d h_{\mathrm{Lca}} l d h_{\mathrm{Strb}}$ or $l d h_{\mathrm{Bcoa}}$ ) into B0013080C followed by two cycles of selection in LB containing gentamicin and LB without gentamicin, yielding strain B0013-090B1(B0013, $\Delta a c k-p t a, \Delta p p s, \Delta p f l B, \Delta d l d, \Delta p o x B$, $\left.\Delta a d h E, \Delta f r d A, \Delta l d h A, \Delta l l d D:: \mathrm{P}_{l d h A}-l d h_{\mathrm{Lca}}\right)$, strain B0013090B2 (B0013, $\Delta a c k-p t a, \Delta p p s, \Delta p f l B, \Delta d l d, \Delta p o x B$, $\left.\Delta a d h E, \quad \Delta f r d A, \Delta l d h A, \Delta l l d D:: P_{l d h A}-l d h_{\text {Strb }}\right), \quad$ or B0013090B3(B0013, $\Delta a c k-p t a, \Delta p p s, \Delta p f l B, \Delta d l d, \Delta p o x B, \Delta a d h E$, $\left.\Delta f r d A, \Delta l d h A, \Delta l l d D:: \mathrm{P}_{l d h A}-l d h_{\mathrm{Bcoa}}\right)$. Deletion of the $l l d D$ gene blocked the reflow pathway from L-lactate to pyruvate catalyzed by the FMN-dependent L-lactate dehydrogenase (Figure 1).

A flask fermentation experiment was carried out at $37^{\circ} \mathrm{C}$ to evaluate the performances of the engineered strains. The results are summarized in Table 3. The total amounts of lactate produced by strain B0013-090B1,

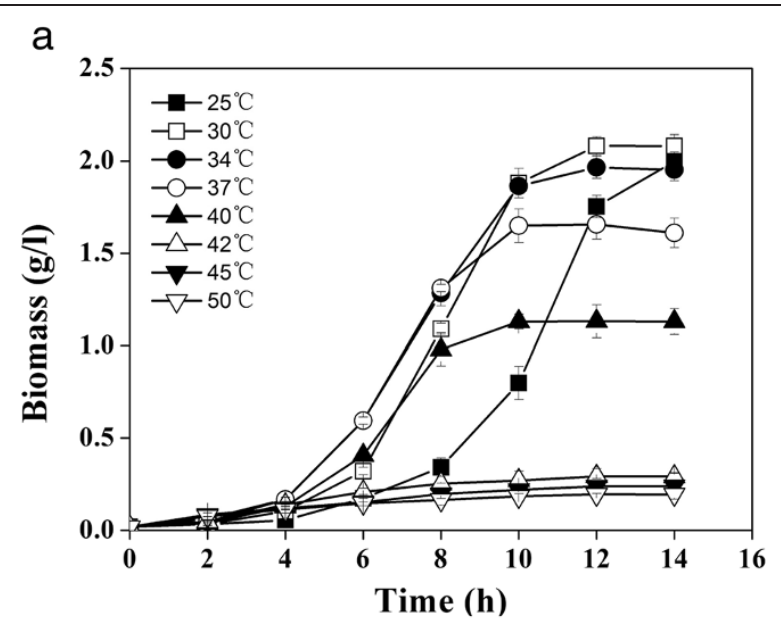

b

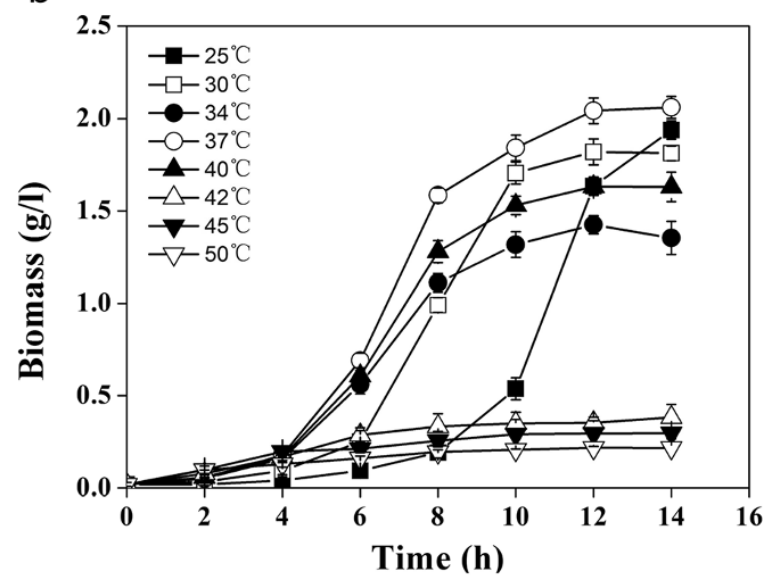

C

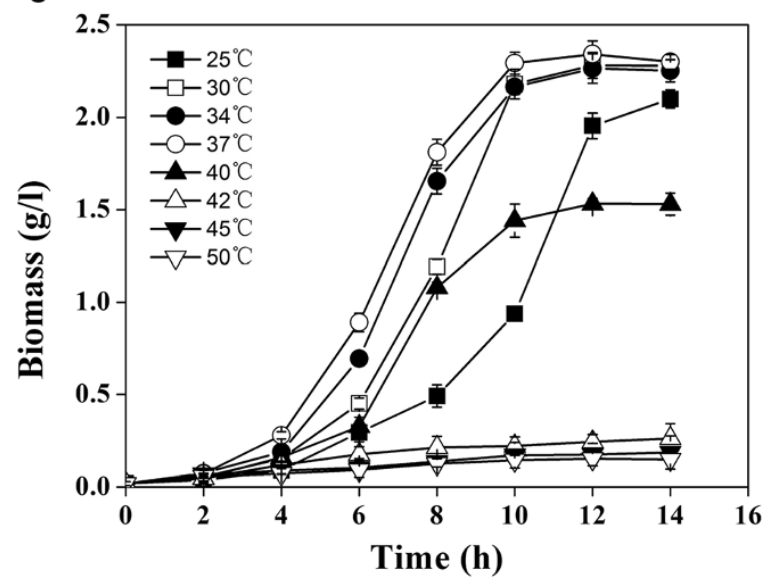

Figure 2 The growth characteristics of E. coli strains 090B1 (a), 090B2 (b) and 090B3 (c) at various temperatures. For the

experiments, a shaking flask fermentation test was carried out in a 250$\mathrm{ml}$ flask with working volume of $50 \mathrm{ml}$ at various temperatures from $25^{\circ}$ $\mathrm{C}, 30^{\circ} \mathrm{C}, 34^{\circ} \mathrm{C}, 37^{\circ} \mathrm{C}, 40^{\circ} \mathrm{C}, 42^{\circ} \mathrm{C}, 45^{\circ} \mathrm{C}$ to $50^{\circ} \mathrm{C}$ for up to $14 \mathrm{~h}$. Sampling was carried out in every 2 hours. The cell density was colorimetrically analyzed at $600 \mathrm{~nm}$. The experiments were carried out in triplicates. 
B0013-090B2 and B0013-090B3 was 20.16, 16.19 and $25.59 \mathrm{~g} / \mathrm{l}$ from $35.0 \mathrm{~g} / \mathrm{l}$ of glucose $(5 \mathrm{~g} / \mathrm{l}$ of glucose in LB medium and $30 \mathrm{~g} / \mathrm{l}$ of glucose was added afterwards), respectively, while the total lactate produced by B0013070 and B0013-080C was $27.27 \mathrm{~g} / \mathrm{l}$ and $0.02 \mathrm{~g} / \mathrm{l}$ respectively. The percentage of L-lactate in the total lactate produced by B0013-090B1, B0013-090B2 or B0013090B3 was above $99.9 \%$, while nearly no L-lactate was produced by B0013-070 and B0013-080C. These results indicated that all three L-lactate dehydrogenases were functionally expressed and capable of catalyzing L-lactate formation, and that D-lactate formation can be blocked thoroughly by deleting the $\operatorname{ldh} A$ gene. It is interesting to note that conversion efficiency of L-lactate and cell growth rate were obviously different among the recombinant E. coli strains carrying a different L-lactate dehydrogenase.

\section{Temperature as a factor for variation in cell growth and L-lactate synthesis}

Since cell growth and L-lactate formation share the same intermediate pyruvate derived from carbon catabolism in E. coli, it is expected that cell growth and L-lactate formation will compete for pyruvate and both processes would be affected by the incubation temperature. However, given the highly sensitive nature of the expressed L-lactate dehydrogenase to temperature, L-lactate formation is more susceptible than cell growth to fermentation temperature.

Strains B0013-090B1, B0013-090B2 or B0013-090B3 heterologously expressing an L-LDH were examined for their growth rate. A flask fermentation test was carried out in a 250-ml flask with working volume of $50 \mathrm{ml}$ at various temperatures from $25^{\circ} \mathrm{C}$ to $50^{\circ} \mathrm{C}$ for up to $14 \mathrm{~h}$.
The cell density was analyzed and the results are summarized in Figure 2. Maximum growth rate was achieved at temperature of $30 \sim 34^{\circ} \mathrm{C}$ for B0013-090B1 and $37^{\circ} \mathrm{C}$ for B0013-090B2 and B0013-090B3. When the cultivation temperature was higher than $42^{\circ} \mathrm{C}$, obvious growth inhibition was observed for all three strains (Figure 2).

Strains expressing different types of L-lactate dehydrogenases had different growth rates when incubated at different temperatures, suggesting that L-lactate dehydrogenase activity may be the key factor. To elucidate the intracellular L-lactate dehydrogenase activity patterns at different temperatures, the cells growing at different temperatures were collected and the intracellular activities determined. The results are summarized in Figure 3. The lactate dehydrogenase activity in B0013-090B3 was much less than that of B0013-090B1 or B0013-090B2 at both $34^{\circ} \mathrm{C}$ and $37^{\circ} \mathrm{C}$. However, B0013-090B3 displayed about 3-fold higher lactate dehydrogenase activity at $42^{\circ} \mathrm{C}$. These results indicate that incubation temperature can work as a sensitive factor to tune the activity of the expressed L-LDH and hence redistributes the metabolic flux between the TCA cycle and pyruvate to L-lactate.

\section{L-Lactate production in a bioreactor using temperature as an adjustable parameter}

As observed above, only E. coli B0013-090B3 harboring a $B$. coagulans L-lactate dehydrogenase gave higher $\mathrm{LDH}$ activity at $\geq 42^{\circ} \mathrm{C}$ and lower $\mathrm{LDH}$ activity at $\leq 37^{\circ} \mathrm{C}$, which enabled us to consider temperature as a useful adjustable parameter for some metabolically-engineered strains. A temperature-shift fermentation process was developed and applied to check the growth and lactate formation efficiencies in a 25-liter bioreactor with final working

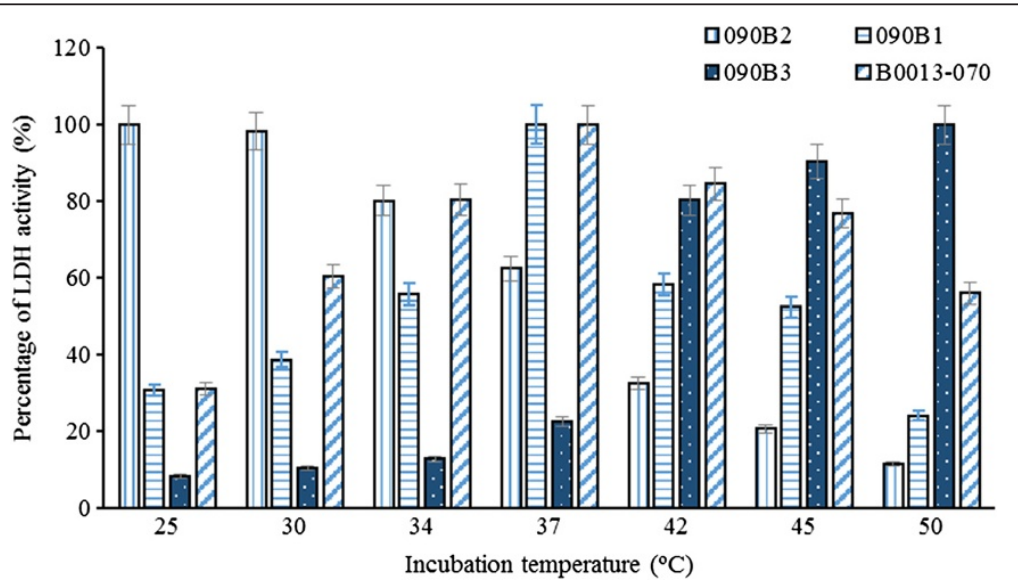

Figure 3 Comparison of recombinant LDH activity expressed by strain 090B1, 090B2 and 090B3. After growing while shaking at 200 rpm for $7 \mathrm{~h}$, the cells were collected and crude cell extracts were prepared. The extracts were assayed for LDH activity at pH 6.5 and at the same temperature as that of incubation (among $25^{\circ} \mathrm{C}, 30^{\circ} \mathrm{C}, 34^{\circ} \mathrm{C}, 37^{\circ} \mathrm{C}, 42^{\circ} \mathrm{C}, 45^{\circ} \mathrm{C}$ or $50^{\circ} \mathrm{C}$ ). The maximum specific LDH activity of each strain was standardized to $100 \%$. The specific LDH activity of their parental B0013-070 was also presented as comparison. The experiments are performed in triplicates. Strain 090B1 showed maximum activity of $\mathrm{LDH}$ at $37^{\circ} \mathrm{C}\left(2.12 \mathrm{U} / \mathrm{mg}\right.$ protein), Strain $090 \mathrm{~B} 2$ yielded activity maximum at $25^{\circ} \mathrm{C}(1.95 \mathrm{U} / \mathrm{mg}$ protein), Strain $090 \mathrm{~B} 3$ showed a activity maximum at $50^{\circ} \mathrm{C}\left(2.43 \mathrm{U} / \mathrm{mg}\right.$ protein). In the parent strain, the highest activity $\left(1.16 \mathrm{U} / \mathrm{mg}\right.$ protein) was at $37^{\circ} \mathrm{C}$. 
Table 4 Comparison of fermentation data (mean \pm range of duplicate experiments) from the bioreactor experiments

\begin{tabular}{|c|c|c|c|c|c|c|c|c|c|c|c|c|}
\hline \multirow[t]{2}{*}{ Strains } & \multirow{2}{*}{$\begin{array}{l}\text { Overall } \\
\text { volumetric } \\
\text { lactate } \\
\text { productivity } \\
(\mathrm{g} / \mathrm{l} \mathrm{h})^{\mathrm{a}}\end{array}$} & \multirow{2}{*}{$\begin{array}{l}\text { Oxygen-limited } \\
\text { volumetric lactate } \\
\text { productivity }(g / l ~ h)^{b}\end{array}$} & \multirow{2}{*}{$\begin{array}{l}\text { Oxygen-limited } \\
\text { specific lactate } \\
\text { productivity } \\
(\mathrm{g} / \mathrm{g} \mathrm{h})^{\mathrm{c}}\end{array}$} & \multirow{2}{*}{$\begin{array}{l}\text { Oxygen-limited } \\
\text { specific glucose } \\
\text { consumption } \\
\text { rate }(g / g h)^{d}\end{array}$} & \multirow{2}{*}{$\begin{array}{l}\text { Aerobic biomass } \\
\text { yield }(\mathrm{g} / 100 \mathrm{~g} \\
\text { glucose })^{\mathrm{e}}\end{array}$} & \multirow{2}{*}{ 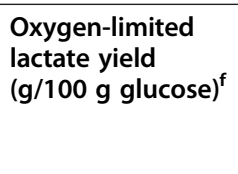 } & \multirow{2}{*}{$\begin{array}{l}\text { Lactate } \\
\text { titer }(\mathbf{g} / \mathbf{l})\end{array}$} & \multicolumn{5}{|c|}{ Yield (g/100 g glucose) (The molar yield) ${ }^{g}$} \\
\hline & & & & & & & & biomass & lactate & acetate & succinate & pyruvate \\
\hline 090B3 ${ }^{h}$ & $2.67 \pm 0.10$ & $3.46 \pm 0.23$ & $0.42 \pm 0.00$ & $0.50 \pm 0.01$ & $36.9 \pm 0.2$ & $83.0 \pm 1.2$ & $\begin{array}{l}106.8 \pm \\
1.1\end{array}$ & $5.8 \pm 0.1$ & $\begin{array}{l}74.3 \pm 1.2(1.49 \pm \\
0.02)\end{array}$ & $\begin{array}{l}0.6 \pm \\
0.1\end{array}$ & $0.3 \pm 0.0$ & $0.0 \pm 0.0$ \\
\hline 090B ${ }^{\mathrm{i}}$ & $4.66 \pm 0.12$ & $6.77 \pm 0.30$ & $0.98 \pm 0.10$ & $0.97 \pm 0.04$ & $36.8 \pm 0.1$ & $97.0 \pm 0.5$ & $\begin{array}{l}142.2 \pm \\
0.7\end{array}$ & $4.9 \pm 0.3$ & $\begin{array}{l}87.0 \pm 2.1(1.74 \pm \\
0.04)\end{array}$ & $\begin{array}{l}0.4 \pm \\
0.1\end{array}$ & $0.1 \pm 0.1$ & $0.1 \pm 0.2$ \\
\hline
\end{tabular}

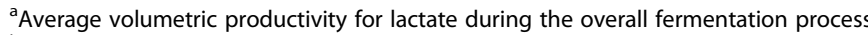

${ }^{\mathrm{b}}$ Average volumetric productivity for lactate during the oxygen-limited phase.

'Average specific lactate productivity during the oxygen-limited phase. The molar yield was also presented in parentheses.

${ }^{\mathrm{d}}$ Average specific glucose consumption rate during the oxygen-limited phase.

${ }^{\mathrm{e}}$ Average biomass yield during aerobic phase.

${ }^{\mathrm{f}}$ Average lactate yield during the oxygen-limited phase.

${ }^{9}$ Average yield during the overall fermentation process.

hThe fermentation was carried out with aerobic cell growth at $37^{\circ} \mathrm{C}$ followed by fermentation at $37^{\circ} \mathrm{C}$

'The fermentation was carried out with aerobic cell growth at $37^{\circ} \mathrm{C}$ followed by fermentation at $42^{\circ} \mathrm{C}$. 
volume of 20 liters. The fed-batch process was started by inoculating fresh inoculum of E. coli B0013-090B3 and cultivated in an aerobic condition at $37^{\circ} \mathrm{C}$ followed by anaerobic fermentation for L-lactate formation initiated by stopping aeration, reducing agitation and elevating temperature to $42^{\circ} \mathrm{C}$ when cell density $\left(\mathrm{OD}_{600}\right)$ reached about 30. The results are summarized in Table 4 and Figure 4. Strain B0013-090B3 produced $142.2 \mathrm{~g} / \mathrm{l} \mathrm{L-}$ lactate with no more than $1.2 \mathrm{~g} / \mathrm{l}$ of total by-products (mainly acetate, pyruvate and succinate). The average volumetric lactate productivity during the oxygenlimited fermentation phase and the lactate yield from glucose was $6.77 \mathrm{~g} / \mathrm{l} \mathrm{h}$ and $97 \%(\mathrm{~g} / \mathrm{g})$, respectively (Table 4). The overall volumetric lactate productivity and the oxygen-limited volumetric lactate productivity were improved up to $74.5 \%$ and $95.7 \%$, respectively in comparison to those at $37^{\circ} \mathrm{C}$ (Table 4).

\section{Discussion}

Metabolic engineering are focusing mainly on the manipulation of directly-related metabolic pathways, which is obtained by introduction and/or amplification of product-oriented pathways or by deletion or attenuation of competing pathways [22,23]. Currently, metabolic engineers tend to finely exploit a pathway or a reaction to make it compatible with the cell physiological properties [11,17,24-26].

Generally, cell growth depends on the synthesis of acetyl-CoA from pyruvate, which also acts as the precursor of lactate. Expression of a lactate dehydrogenase results in a certain percentage of pyruvate converted to lactate, thereby limiting metabolic flux for cell synthesis and eventually retarding cell growth. Specific to E. coli, intracellular activity level of the lactate dehydrogenase depends not only on the transcription and translation levels of its encoding gene, which is mainly affected by the unique cellular microenvironment in E. coli, but also on its original native biochemical properties as well. Due to these concerns, fine control of the transcription and translation of $l d h A$ encoding $\mathrm{NAD}^{+}$-dependent D-lactate dehydrogenase and the intracellular activity level of the D-lactate dehydrogenase in D-lactate production was found to significantly improve both lactate yield and cell growth rate [11,17]. In that case, a novel strategy has been developed for finely-regulating lactate dehydrogenase expression in $E$. coli, in which a gene encoding a lactate dehydrogenase was under the control of a thermoinduced promoter $[11,24]$. In a bioreactor experiment using scaled-up conditions, strain B0013-070B produced $122.8 \mathrm{~g} / \mathrm{l}$ D-lactate with an increased oxygen-limited productivity of $0.89 \mathrm{~g} / \mathrm{g} \mathrm{h}$ [11].

Most enzymes have a native temperature optimum but some have a broader plateau in activity for a certain temperature range. On the other hand, the enzymes
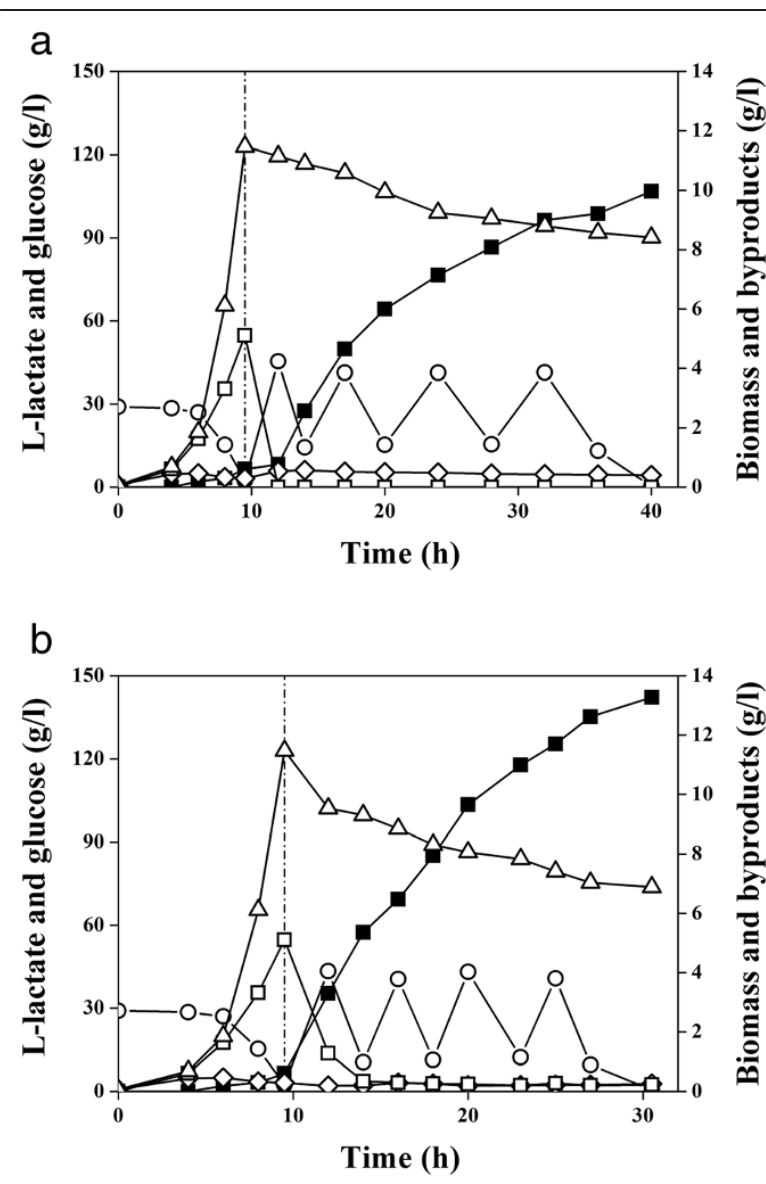

Figure 4 Representative experiments (conducted in duplicate) showing production of organic compounds and dry cell mass during the aerobic and oxygen limited lactate fermentation by E. coli B0013-090B3 in a $25-I$ bioreactor. The dotted line indicates the time when the culture was shifted from the aerobic cultivation to the oxygen limited production phase. Additions of glucose of 136.2, $136.2,150.9$ and $136.2 \mathrm{~g}$ were made to the bioreactor during the production phase. Open triangle: dry cell mass, closed square: lactate, open square: pyruvate, open diamond: acetate; open circle: glucose concentration. (a) The aerobic cultivation was carried out at $37^{\circ} \mathrm{C}$ with dissolved oxygen greater than $30 \%$ saturation by supplying $3-7 \mathrm{l} / \mathrm{min}$ air and 200-1000 rpm of agitation. The production phase was done at $37^{\circ} \mathrm{C}$ with $100 \mathrm{rpm}$ of agitation and without aeration. (b) The aerobic cultivation was carried out at $37^{\circ} \mathrm{C}$ with dissolved oxygen higher than $30 \%$ saturation by supplying 3-7 I/min air and 200-1000 rpm of agitation. The production phase was done at $42^{\circ} \mathrm{C}$ with $100 \mathrm{rpm}$ of agitation and without aeration.

belonging to the same super-family originating from different (micro-)organisms carry out the same reaction yet may show the different temperature optima. The effect of temperature on the activity of an enzyme are complex and can be considered as two forces acting simultaneously but in opposite directions. As the temperature is raised, the rate increases, but at the same time there exists a progressive inactivation (denaturation) of the enzyme protein. From the metabolic engineering's point of view, temperature may become one of the most 
important factors that can be used to control the enzyme activity in a pathway and hence finely regulate the metabolic flux. In present case we used temperature to optimize the cell growth and L-lactate production.

In present studies, three L-lactate dehydrogenases with different temperature optima were functionally expressed in $E$. coli. The recombinant $E$. coli strain harboring an L-LDH from $B$. coagulans exhibited lower L-LDH activity at $37^{\circ} \mathrm{C}$ or below thus allowing robust cell growth at this temperature (Figures 2,3). On the other hand, the enzyme showed higher activity at $42^{\circ} \mathrm{C}$ or above, which allowed cells to convert pyruvate to L-lactate efficiently, and the L-lactate titer reached $142.2 \mathrm{~g} / \mathrm{l}$ (Figure 4, Table 4). To our knowledge this is the highest level of L-lactate production by recombinant $E$. coli cells ever reported.

The recombinant $E$. coli cells expressing an L-LDH from $L$. casei displayed a slow growth phenotype during the aerobic phase at $37^{\circ} \mathrm{C}$, which can be attributed to the insufficient supply of substrate for cell growth due to channeling of metabolic flux by the effects of higher L-lactate dehydrogenase activity at the growth temperature (Figures 2,3). Normal growth of the recombinant cells expressing the L-LDH from B. coagulans or Str. bovis was observed at $37^{\circ} \mathrm{C}$, consistent with the lower activity of L-lactate dehydrogenase at this temperature (Figures 2, 3). These observations strongly suggest that it would be essential to either investigate the enzymatic properties or use a combination of promoter, temperature or $\mathrm{pH}$ conditions of a specific target enzyme before engineering a metabolic pathway. Different requirements for cell growth and target product formation conferred by a target enzyme can be utilized to rationally design and construct efficient metabolic pathways. Additionally, the desired enzymatic properties of a specific enzyme referred to a specific pathway or a reaction can be obtained either by cloning of genes obtained from microorganisms of extensive bio-diversity $[27,28]$ and/or by gene manipulation in the laboratory using modern molecular tools $[29,30]$.

In conclusion, the rapid growth characteristics and clearly defined metabolic pathway information in E. coli make it one of the most excellent lactate producers. The scale-up production of lactate by $E$. coli was limited by the competition relationship between cell growth and lactate synthesis in which lactate dehydrogenase activity is a critical factor. Furthermore, as described in present studies, properties, especially the thermodynamics of an enzyme can be effectively used as a powerful alternative tool to finely regulate a metabolic pathway and its metabolic flux by controlling temperature during cultivation/ fermentation. This approach is convenient and economical to operate in any biotechnological process.

\section{Competing interests}

The authors declare that they have no competing interests.

\section{Authors' contributions}

DN conceived the study, participated in its design and carried out the molecular genetic studies. KT carried out the molecular manipulation and the fermentation experiments. DN, KT, BAP, MW, ZW, FL and SS analyzed the data and prepared the manuscript. All authors read and approved the final manuscript.

\section{Acknowledgments}

This work is partly supported by the Science and Technology Development Foundation of Tianjin Higher Education (20130628), the program for Changjiang Scholars and Innovative Research Team in University (IRT1166), SA-China Joint Project (CS06-L11). We thankfully thank Prof. Xiaoguang Liu from Tianjin University of Science and Technology for his assistance and kind revision in manuscript preparation.

\section{Author details}

${ }^{1}$ Key Laboratory of Industrial Fermentation Microbiology, Ministry of Education \& The College of Biotechnology, Tianjin University of Science \& Technology, Tianjin 300457, China. ${ }^{2}$ Department of Microbiology, Stellenbosch University, Private Bag X1, Matieland 7602, South Africa. ${ }^{3}$ Department of Biotechnology \& Food Technology, Faculty of Applied Sciences, Durban University of Technology, P.O. Box 1334, Durban 4001, South Africa.

Received: 28 January 2014 Accepted: 11 May 2014

Published: 29 May 2014

\section{References}

1. John RP, Nampoothiri KM, Pandey A: Fermentative production of lactic acid from biomass: an overview on process developments and future perspectives. Appl Microbiol Biotechnol 2007, 74:524-534.

2. Jem K, van der Pol J, De Vos S, Chen GG-Q: Microbial lactic acid, its polymer poly(lactic acid), and their industrial applications. In Plastics from Bacteria: Natural Functions and Applications. Edited by Chen GG-Q. Heidelberg: Springer Berlin; 2009:323-346. pp. 14, 323-346.

3. Datta $R$, Henry M: Lactic acid: recent advances in products, processes and technologies-a review. J Chem Technol Biotechnol 2006, 81:1119-1129.

4. Garrison AW: Probing the enantioselectivity of chiral pesticides. Environ Sci Technol 2006, 40:16-23.

5. Lasprilla AJ, Martinez GA, Lunelli BH, Jardini AL, Filho RM: Poly-lactic acid synthesis for application in biomedical devices - a review. Biotechnol Adv 2012, 30:321-328.

6. Niju N, Pradip KR, Aradhana S: L (+) lactic acid fermentation and its product polymerization. Electron J Biotechnol 2004, 7:167-179.

7. Okano K, Tanaka T, Ogino C, Fukuda H, Kondo A: Biotechnological production of enantiomeric pure lactic acid from renewable resources: recent achievements, perspectives, and limits. Appl Microbiol Biotechnol 2010, 85:413-423.

8. Chang DE, Jung HC, Rhee JS, Pan JG: Homofermentative production of D- or L-lactate in metabolically engineered Escherichia coli RR1. Appl Environ Microbiol 1999, 65:1384-1389.

9. Dien BS, Nichols NN, Bothast RJ: Fermentation of sugar mixtures using Escherichia coli catabolite repression mutants engineered for production of L-lactic acid. J Ind Microbiol Biotechnol 2002, 29:221-227.

10. Zhou L, Zuo ZR, Chen XZ, Niu DD, Tian KM, Prior BA, Shen W, Shi GY, Singh $S$, Wang ZX: Evaluation of genetic manipulation strategies on D-lactate production by Escherichia coli. Curr Microbiol 2011, 62:981-989.

11. Zhou L, Niu DD, Tian KM, Chen XZ, Prior BA, Shen W, Shi GY, Singh S, Wang ZX: Genetically switched D-lactate production in Escherichia coli. Metab Eng 2012, 14:560-568.

12. Zhu Y, Eiteman MA, DeWitt K, Altman E: Homolactate fermentation by metabolically engineered Escherichia coli strains. Appl Environ Microbiol 2007, 73:456-464.

13. IImén M, Koivuranta K, Ruohonen L, Rajgarhia V, Suominen P, Penttilä M: Production of I-lactic acid by the yeast Candida sonorensis expressing heterologous bacterial and fungal lactate dehydrogenases. Microb Cell Fact 2013, 12:53.

14. Mazumdar S, Blankschien MD, Clomburg JM, Gonzalez R: Efficient synthesis of L-lactic acid from glycerol by metabolically engineered Escherichia coli. Microb Cell Fact 2013, 12:7. 
15. Zhao J, Xu L, Wang Y, Zhao X, Wang J, Garza E, Manow R, Zhou S: Homofermentative production of optically pure L-lactic acid from xylose by genetically engineered Escherichia coli B. Microb Cell Fact 2013, 12:57.

16. Zhou S, Shanmugam KT, Ingram LO: Functional replacement of the Escherichia coli D-(-)-lactate dehydrogenase gene (IdhA) with the L-(+)-lactate dehydrogenase gene (IdhL) from Pediococcus acidilactici. Appl Environ Microbiol 2003, 69:2237-2244.

17. Zhou L, Shen W, Niu DD, Tian KM, Prior BA, Shi GY, Singh S, Wang ZX: Fine tuning the transcription of IdhA for D-lactate production. J Ind Microbiol Biotechnol 2012, 39:1209-1217.

18. Zhou L, Tian KM, Niu DD, Shen W, Shi GY, Singh S, Wang ZX: Improvement of D-lactate productivity in recombinant Escherichia coli by coupling production with growth. Biotechnol Lett 2012, 34:1123-1130.

19. Sambrook J, Russell DW: Molecular Cloning: a Laboratory Manual. New York: Cold Spring Harbor Laboratory Press; 2001

20. Zhou L, Niu DD, Li N, Chen XZ, Shi GY, Wang ZX: Multiple gene inactivation approach in Escherichia coli mediated by a combination of red recombination and Xer recombination. Microbiol China 2010, 37:923-928.

21. Zhou S, Shanmugam KT, Yomano LP, Grabar TB, Ingram LO: Fermentation of $12 \%(\mathrm{w} / \mathrm{v})$ glucose to $1.2 \mathrm{M}$ lactate by Escherichia coli strain SZ194 using mineral salts medium. Biotechnol Lett 2006, 28:663-670.

22. Bailey JE: Toward a science of metabolic engineering. Science 1991, 252:1668-1675

23. Keasling JD: Manufacturing molecules through metabolic engineering. Science 2010, 330:1355-1358.

24. Chen XZ, Zhou L, Tian KM, Kumar A, Singh S, Prior BA, Wang ZX: Metabolic engineering of Escherichia coli: a sustainable industrial platform for bio-based chemical production. Biotechnol Adv 2013, 31:1200-1223.

25. Kim HJ, Hou BK, Lee SG, Kim JS, Lee D, Lee SJ: Genome-wide analysis of redox reactions reveals metabolic engineering targets for D-lactate overproduction in Escherichia coli. Metab Eng 2013, 18:44-52.

26. Ma SM, Garcia DE, Redding-Johanson AM, Friedland GD, Chan R, Batth TS, Haliburton JR, Chivian D, Keasling JD, Petzold CJ, Lee TS, Chhabra SR: Optimization of a heterologous mevalonate pathway through the use of variant HMG-CoA reductases. Metab Eng 2011, 13:588-597.

27. DeLong EF: The microbial ocean from genomes to biomes. Nature 2009, 459:200-206.

28. Prakash $\mathrm{O}$, Shouche $\mathrm{Y}$, Jangid K, Kostka JE: Microbial cultivation and the role of microbial resource centers in the omics era. Appl Microbiol Biotechnol 2013, 97:51-62.

29. Bornscheuer UT, Huisman GW, Kazlauskas RJ, Lutz S, Moore JC, Robins K: Engineering the third wave of biocatalysis. Nature 2012, 485:185-194.

30. Goldsmith M, Tawfik DS: Enzyme engineering by targeted libraries. Methods Enzymol 2013, 523:257-283.

doi:10.1186/1475-2859-13-78

Cite this article as: Niu et al: Highly efficient L-lactate production using engineered Escherichia coli with dissimilar temperature optima for L-lactate formation and cell growth. Microbial Cell Factories 2014 13:78.

\section{Submit your next manuscript to BioMed Central and take full advantage of:}

- Convenient online submission

- Thorough peer review

- No space constraints or color figure charges

- Immediate publication on acceptance

- Inclusion in PubMed, CAS, Scopus and Google Scholar

- Research which is freely available for redistribution 